\title{
Audiobooks for Assisting EFL Students in Reading Independently
}

\author{
Muhammad Riswanda Imawan \\ Yogyakarta State University \\ muhammad.riswanda.2017@student.uny.ac.id \\ Ashadi \\ Yogyakarta State University \\ ashadi@uny.ac.id
}

\begin{abstract}
Scholars and practitioners have done much research in developing EFL students' reading skill so that they can recall the main points of a text, answer literal and/or inferential questions, and even complete the actual reading of the text. Yet, those mainly have to involve the presence of a teacher or tutor for monitoring whereas students should be trained to be independent in reading. By reviewing related literature, this article is suggesting to use 'Audiobook' to assist EFL students in reading independently. This article describes how the teaching of reading for EFL students, and how audiobooks can contribute to it. This all finally come with a conclusion that audiobook definitely can assist EFL in students in reading independently that later will supportively develop their reading skill and language competence besides their listening skill itself.

Keywords: Audiobook, learning media, the teaching of reading, EFL
\end{abstract}




\section{INTRODUCTION}

Reading as one of the skills that language students have to acquire and develop still generates problems for some students whereas Whittingham, Huffman, Christensen, and McAllister (2013) believed that "Reading comprehension and interest are essential in learning" (p. 2). In the context of EFL, teachers can apply various ways for the matters of teaching reading to students. teachers can promote extensive reading and intensive reading to their students to develop their reading comprehension (Alyousef, 2006), and use media, like music, into daily instruction and practical activities for classroom implementation (Paquette \& Rieg, 2008). All of those ways of teaching reading have been proved successful to support students to develop reading skill, but those demand the existence of the teacher around students while these days, students are expected to do or develop their reading independently, or when they are not with their teachers supporting around.

As technologies have been daily companies to students these days, the idea of teachers developing technological competences and skills, and promoting the use of technology for learning (Anas \& Musdariah, 2018) in order get students more interested and more comprehend in reading can be a great idea to be considered. This strategy of integrating technology into teaching-learning would encourage students better as Maboe, Smith, Banoobhai, and Makgatho (2018) found the use of modern technology, like 'tablet', can enhance teaching and learning in education when using it to draw students into listening and reading English activities. Larson (2015), by using 'Kindle', also succeeded in extending students' reading experience digitally through the combined use of e-books and audiobooks that students became more motivated and more comprehend in reading. Thoughtfully, promoting the use of technology to help students develop reading skill and comprehension independently is actually possible and doable.

In supporting the suggestion of using technology to support EFL students struggling in reading independently, audiobook is one of many that can benefit for this matter. Some reviewed literature related to this issue will exceed the explanation of using audiobook to support EFL students' reading. The synthesis among teaching reading, the importance of audiobook (what it is and what it is for), and the application of audiobook in language learning is the points covering this issue, to explain further how to utilize audiobook for assisting students in reading independently. Therefore, it will conclude how students can take benefits from using audiobook in reading independently.

\section{TEACHING READING FOR EFL STUDENTS}

Many scholars and practitioners have been contributing to help teachers on how to teach reading to students. For beginning readers, Rigg proposed the Language Experience Approach (LEA), in which the basic technique suggests teachers use students' ideas and students' own words in the preparation of the beginning reading materials (as cited in Carrell \& Eisterhold, 1983). Additionally, Krashen (2004) recommended to do a narrow reading that limits reading to a single topic or to the texts of a single writer, and also, Kendeou, Van Den Broek, Helder and Karlsson (2014) gave a bit of advice for teachers to make own texts by adapting texts according to the purposes. This is to activate students' background knowledge so that they can take meaning from the reading (Brown, 2007). Providing appropriate reading materials for students should be 
considered carefully by teachers when they will teach reading before they set instructions or tasks for students.

The teaching to develop students' reading skill may require tasks involving other skills, such as writing, listening and speaking. Brown (2007) alleged that reading skill develops best when it is integrated with such activities that include writing, listening and speaking, and the relationship of reading-writing will deal the most. Writing tasks have a great positive impact on the development students' reading skill that it becomes a reciprocal process for both writing and reading development (Stone, 2008), and from another perspective's belief, EFL students will develop their reading skill if they develop their proficiency in speaking as well. Hence, the integration among skills is beneficial to develop students' reading skill here.

For the process of teaching reading itself, it is good to have pre-reading activities at the beginning. The pre-reading activities, such as asking students questions that arouse their interest while previewing the text, will help activate the relevant schema of the whole reading process and it can increase student motivation before the actual reading takes place (Alyousef, 2006). Then, teachers can give an overview of what students are going to read (Drucker, 2003), or have more activities like a discussion of titles, subheadings or photographs (Abraham, 2002). This prereading stage is about building the relationship between the text and the students, and it will have students ready to face the actual reading.

The next stage of the reading teaching process is while-reading. The while-reading stage contains activities where students will develop their linguistic and schematic knowledge to completely conquer the text, and to be flexible in this stage, teachers can use both top-down and bottom-up process (Alyousef, 2006). To do bottom-up processing, students firstly should have learned about the multiplicity of linguistic signals, such as letters, morphemes, syllables, words, phrases, grammatical cues and discourse markers, then proceeding it to making sense, cohering and taking meaning, whereas to do top-down processing encourage students to do a puzzle-solving process, infer meaning by drawing on their own intelligence and experience to understand a text while reading (Brown, 2007). Here, teachers can teach students using techniques like skimming, scanning, predicting and identifying main ideas to increasing fluency (Anderson as cited in Brown, 2007). Moreover, Kendeou et al. (2014) pertain such interventions during reading, such as asking questions that lead attention to the important or central information in texts, satisfyingly can help students struggling with the reading and develop their reading comprehension skill. As the while-reading stage has been planned before, the whole tasks should be intended to give students 'power' to tackle the text.

After the actual reading activities finished, one or some post-reading activities are needed to strengthen and maintain their reading skill. Here, exercises or games can be given to students. Haller proposed interactive activities like matching exercises, cloze exercises, cut-up sentences, and comprehension questions (as cited in Alyousef, 2006). This stage of post-reading will enhance the whole learning comprehension of students.

One that cannot be missed out when teachers want to develop students' reading skill is the pleasure of reading itself that also plays an important role. Here, extensive reading or 'reading for pleasure' of longer text with little or no conscious strategic intervention is especially beneficial for students learning a foreign language/EFL as some researchers has argued that extensive reading is a key to develop reading skill, linguistic competence, vocabulary, spelling and writing skill of the students (Brown, 2007). Reading for pleasure is to motivate students to be more 
engaged to the reading itself (Stone, 2008), and as their engagement to the reading grows, their reading skill will grow as well (Harmer, 1998). At this moment, extensive reading or reading for pleasure must be considered as a real, valuable approach provided to students in order to increase their reading skill.

Even though many approaches have suggested many ways, teachers still can teach reading more attractively by utilizing media as the growth of technology has advanced or changed the way students learn these days. Holum and Gahala (2001) suggested the use of some media, such as audiobook, electronic books and online books, electronic talking books, and programmed reading instruction, to support students' reading development. Thus, the use of media or technology in the teaching of reading might fits the way students learn these days as they happen to use technology in daily activities.

\section{LISTENING TO AUDIOBOOKS AS A NEW WAY TO READING}

Audiobook, also called 'books on tape', is the other version of fiction or nonfiction books that are audio-taped professionally in full-length or without uncut (Holum \& Gahala, 2001, p. 6). An audiobook is the sounded or spoken narrative version of the original book, in which for more preferable audiobooks, the content is still unedited. At this point, people will still have the same content of audiobook compared with the printed one, but they may experience different thrills by listening to an audiobook, and it may be as pleasant as reading the actual print book as told by its users.

By history, the users of audiobook were originally aimed to be visual-impaired people, in which it is to assist them reading a book, so they can enjoy and understand the books (Ayunda, 2015). However, its growth through decades has expanded its users. King-Sears, Swanson, and Mainzer noted the innovations and the marketability of technology have led to a drastic increase in the offerings of electronic media of literacy, including audiobooks (as cited in Whittingham et al., 2013). This phenomenon has been seen, in which the users of audiobook have been steadily growing since the 1980s when some people discovered that the comfortableness in using audiobook that it helps people fulfill in their commuting or jogging time (Shokoff, 2001). It is as people can listen (to music) while jogging or driving, but they cannot read (a book) at the same time.

How listening to audiobooks can be valuable similar to reading print books? Irwin (2009) impressed that listening to an audiobook is reading after all even though reading books and listening to audiobooks are slightly different skills, but they are actually directed at the same object. However, some people perceive using/listening to an audiobook is not "reading", or even considered as cheating (Larson, 2015). Additionally, Richards described three lacks of audiobook compared to print book: they do not allow the readers/listeners to find their own sense of the voice telling the story, they do not permit the sensuous experience of feeling a book and being visually aided, and they are often abridged which do not give the fullness of the original (as cited in Shokoff, 2001, p. 172). It is acceptably true that audiobook absolutely feels different from print books, but on the other hand, the first two lacks of audiobook described can be the strengths or the uniqueness of audiobook itself; for the third lack, it is unfortunate if the content of the original is abridged, but there are so many unabridged audiobooks to be enjoyed. Irwin (2009) reminded people who have mistrust over audiobook that audiobook contains people performing reading out 
loud, which is done casually by people like reading bed stories. Looking back at the people who enjoy the audiobook, they find that "Reading with the ears can be a different and not necessarily inferior experience to reading with the eyes" (Shokoff, 2001, p.172). To the people who care about literacy experience, audiobooks are just another medium to present literacy besides "print books". The difference between audiobook and print book is only the package because literature can be packaged differently to many forms (Shokoff, 2001, p. 179). Enjoying print books and audiobook can be analogized to consuming fruits by eating and by drinking juice.

The discussion of this issue leads to a statement that audiobook is not for everyone as some people still prefer consuming fresh fruits rather than drinking juice. Irwin (2009) realized that anyone does not fit to audiobook indeed, it is more suitable for auditory people (learners) than visual people who enjoy seeing/reading books. The comfort audiobook gives is the feelings of listening acquired by segmented people as audiobook allows people into an enhanced literacy experience which substitutes the visual understanding of written words with the auditory understanding of written (spoken) words (Larson, 2015). It is understandable if some people cannot enjoy audiobook since they all have their own preference of enjoying books, but to be precise, reading with ears should be valued at least. Therefore, it is fair to say that listening to audiobooks can be as good as reading the print books, and it is up to the users of both kinds of book, which is more preferable and comfortable for them.

\section{TEACHING READING WITH AUDIOBOOK IN EFL CONTEXT}

Since audiobook has become more popular as time goes by, students become interested in this media as well. Yingling (1998), in her thesis, cited a survey done by an audiobook store in Huston saying that one of three categories of audiobook listeners is those who listen for education and a publisher of romance novel found that most of the listeners of their audiobooks are collegeeducated people. Looking at that event, audiobook has attracted academic people, and with its 'audio-recorded' uniqueness, has been used (can be organization or institution), not just for 'fun', but also for education. It is an innovative technology that is useful for people, including students, to find another way of enjoying some books, and audiobook seems becoming a potential technology that can be utilized into learning and teaching at schools or institutions.

These days with the technology advancement, learning and teaching will be better and more interesting in the process and in the result if technology is utilized into it. MacArthur, Ferretti, Okolo, and Cavalier (2001) even believed that involving technology in learning and teaching can support students acquire literacy skills. Teachers with the ability and knowledge of integrating technology into teaching and learning will be required in here (Anas \& Musdariah, 2018). For this sake, teachers can promote audiobook as a technology to help students reading (listening) books in order to develop their literacy skill, especially reading. Grover and Hannegan (2012), in their book entitled 'Listening to Learn: Audiobooks Supporting Literacy', proposed the use of audiobook to support students' literacy skill of reading when they noticed that some students have reading difficulty that makes them do not acquire the love of reading and the satisfaction of a story in books. There have been many kinds of research concerning the advantages of using audiobooks in learning in order to assist struggling students in reading. Grover and Hannegan (2012) explained that audiobooks get rid of the decoding struggle from students, help students recall details, understand sequence, make predictions, draw a conclusion, make inferences, and retell the information of the book, and it later results in the students' increasing interest and enjoyment 
for reading. Moreover, the use of audiobooks here indeed helps students develop a positive attitude toward reading (Whittingham, 2013). For students who encounter reading challenges, audiobook might be the media that can assist them in reading if teachers willingly promote the use of audiobook in reading activities in the class.

In the field of learning and teaching, there is a strategy or activity called reading aloud, and audiobook works similarly like that reading aloud activity, which the person's (teacher) voice who is reading the book in reading activity is substituted by other's voice in audiobook (Larson, 2015). Audiobooks can ease teachers' role in reading activity at the class that teachers can let audiobook do the reading-for-students, and it would be very helpful for non-native foreign language teachers. Audiobooks are well-considered to be assistance for this activity featuring stellar narrators and a wide variety of formats (Grover \& Hannegan, 2012, p.1). If reading aloud is also usually accompanied by the print book on students' hand, the use audiobook may require the actual (print or electronic) book for students to hold and read while listening to the audiobook. Grover and Hannegan (2005) suggested that, besides the read-aloud session, the use of audiobook can be incorporated with a project like a book report. So many scholars (teachers and practitioners) have done this reading-while-listening activity for students (Ayunda, 2015). As an example, Larson (2015) in his work with a school teacher and his students integrating the use of e-books and audiobooks with student-centered instructional approaches, found tremendous excitement and growing confidence as they engaged in the customized reading. In Larson's cooperative work (2015), students showed the development of literacy skills and the customized reading motivated and engaged them, and further, they also improve their language learning as they learn vocabularies better together with how to pronounce and use them. It happens that way as students listen to a someone (good native readers or narrators) reading the book for them will indirectly unbind them from reading itself, let it flow, as they are not burdened with hesitation whether or not I need to continue the reading if I do not understand some words. According to the stud, students show better improvement both in reading motivation and enjoyment causing them to be a better, more fluent, reader as well since they are exposed to more fluent (native) readers.

Using audiobook in reading activities at class will enable students to acquire improvement in the speaking skill of foreign language too. As Ayunda (2015), through her experimental research to help students understand story from a book (including vocabularies used in the story) by instructing students to listen to audiobook after reading a passage of the book, found that EFL students that are exposed with audiobook during reading activity at the class turns out to be more fluent and use more varied vocabularies than non-exposed students in the foreign language conversation. The exposure of authentic materials given to students by audiobook is the actual use of audiobook in learning and teaching of foreign or second languages as Larson (2015) and Ayunda (2015) did for foreign or second language students, and the results of their research show significant improvement performed by students in terms of comprehension and language skills. The more exposure of the language use is given to students, the more comprehension of the language use is acquired by students.

The use of audiobook in learning and teaching, especially in language subjects, focuses on improving students' reading skill as they need an amount of reading. Moreover, the other skill like speaking improves as well along with the reading skill. Therefore, even though some people say listening audiobook is not the actual reading, audiobook still helps people, like students, read and 
fulfill their need of reading, and based on researches, the implementation of audiobook at classroom for EFL learning and teaching positively results in a significant improvement for students' reading skill, even speaking, and the comprehension as well.

\section{AUDIOBOOK TO SUPPORT EFL STUDENTS' READING INDEPENDENTLY}

There must be some students who still need to improve their reading as they learning English as foreign a language. One of the causes that make EFL students troubled for improving their reading is the less practice for reading itself since the students themselves read less frequently and more slowly (MacArthur et.al., 2001). By what many scholars have explained, students with this situation can be aided with the implementation of audiobooks in the class. The challenges of acquiring knowledge or information, decoding words (phrases and sentences), recalling some details, understanding sequence, making predictions, drawing conclusions, making inferences, and retelling the information of the book are hard for the reluctant students can be eased by utilizing a supporting media like audiobook (Grover \& Hannegan, 2012). According to Byrom's study (1998), audiobooks can motivate failing and disinterested readers. To have it successful, more determined efforts are required to be done by the students because teachers, unfortunately, do not have much time to develop their reading skill at class (Wolfson, 2008). Initiatively, those students who find reading hard need to have more reading practices outside the classroom in order to gain appropriate reading. Since they can have their teachers all the time, they need media as an assistant. To overcome this issue, the audiobook can fulfill the requirement to do the job, in which students can do the reading-listening independently by their own if they have it on their hand.

As listening to an audiobook is considered similar to read aloud done by teachers (other people) for students in the class, this activity possibly can be taken out of the class. Grover and Hannegan (2005) pointed out one of the benefits of listening to audiobook is students can independently listen to it as it encourages the enjoyment of literature as Vygotsky highlighted that the assistance of audiobook in reading serves as that allows students to read at an independent reading level (as cited in Whittingham et al., 2013, p. 3). Practically, students can try listening to audiobooks while doing their daily activities. Taking a look at how audiobook was used by people to accompany them while commuting or jogging (Shokoff, 2001), this integrated activity is doable for students outside the class or while working on everyday jobs. According to a survey, $65 \%$ of audiobook listeners imbibe books while driving; $52 \%$ while relaxing into sleep; and $45 \%$ while doing housework or everyday jobs (Robinson, 2018). To listen to an audiobook is so flexible that people can listen to it while doing what they are doing. If students do this such a way, they can speed up their reading, and later, they independently will improve their reading skill and language competence throughout the process (Grover \& Hannegan, 2012). Hence, students should be encouraged to practice this listening audiobook at home while doing daily activities, and it is worth a try.

The advanced technologies, gadgets such as smartphone and tablets, are very familiar with students these days. Fortune for the students, audiobooks can be accessed and played through those gadgets by students easily any time. Many features and affordable apps provide audiobook in smartphones or tablets to help facilitate students' reading and language development, which are usually all available in English, and to increase students' interest in both reading and language (Maboe et al., 2018). These features presenting audiobook in smartphone and tablet will be a good 
reading company for students. It is absolutely beneficial for EFL students to develop their reading skill and language competence that it later will lead them to better achievement.

To achieve the more significant effect, the integrated use of audiobook and e-book or the print book is strongly recommended. Holding the actual book (print or electronic) while listening to the audiobooks can motivate students to read, in which Larson's (2015) study shows that students feel more excitement in reading while reading e-books accompanied by the audiobooks, their literacy skills also enhance, and their language learning has improved as well. Those advantages are very beneficial for foreign language learners, EFL learners, that they can improve their reading skill and comprehension, and their language learning as well. Thus, since the audiobook can give enjoyment in reading and improve the quality of reading at the same time, language learners, especially EFL students, can utilize it in their daily reading activity, and more importantly, they can do it independently without the existence of their teachers to monitor them.

\section{CONCLUSION}

The debate of the use of audiobooks for supporting students' reading still happens indeed, in which some people still perceive it cheating in reading. It is true that real reading will never be replaced by listening. However, with its uniqueness of narratively telling, audiobooks provably can be a useful media to help students who have troubles in reading to gain information from books and develop literacy skills (reading and writing) besides listening skill itself. Its involvement in the educational field has developed from its original purpose to help impaired people to its use for learning and teaching. Many scholars and practitioners have conducted research about the implementation of audiobook at classroom learning and teaching, and it turns out that audiobook is great potential for improving students' reading comprehension and skill. Further, the satisfaction of listening to audiobooks is also as good as the satisfaction of reading print books. Its benefits in literacy context will definitely help students fitting in reading needs demanded by school or education system (curriculum).

As to assist students in fulfilling reading needs for school, the use of audiobook can be done independently by students. For EFL students, it enables them to be autonomous in learning, especially reading. They can use or hear the audiobook along with reading the print book or ebook that audiobooks can be accessed through gadgets like smartphones and tablets, and those kinds of gadget are very familiar with students these days. Audiobooks in form of apps installed on the gadgets are usually available in English, and this is good news for EFL students. Practicing this listening while reading strategy will lead them to be ready and understand the book as it feels like someone reads it for them with a correct and clear way of reading (pronunciation and stress). The meaning and information of the text, therefore, can be gained through this strategy, and further, this can develop students' language (English) competence. To end this essay, the writer of this essay suggests that further research might be needed to prove or disprove this essay, but the writer could finally and confidently want to say to EFL students that "audiobook is a good friend for students". 


\section{REFERENCES}

Abraham, P. (2002). Skilled Reading: Top-down, bottom-up. Field Notes,10(2), 1.

Alyousef, H. S. (2006). Teaching reading comprehension to ESL/EFL learners. Journal of Language and Learning, 5(1), 63-73.

Anas, I., \& Musdariah, A. (2018). Being an E-Teacher: Preparing the ESL Teacher to Teach English with Technology. Journal of English Language Teaching and Linguistics, 3(1), 4156.

Ayunda, A. N. (2015). The effect of audiobook use on EFL students' fluency development. Journal on English as a Foreign Language, 3(2), 85-92.

Brown, H. D. (2007). Teaching by principles: An interactive approach to language pedagogy. New York: Pearson Education.

Byrom, G. (1998). If you can't read it then audio read it. Reading, 32(2), 3.

Carrell, P. L. \& Eisterhold, J.C. (1983). Schema theory and ESL reading pedagogy. TESOL Quarterly, 17(4), 553-573.

Drucker, M. J. (2003). What reading teachers should know about ESL learners. The Reading Teacher, 57(1),22-29.

Grover, S., \& Hannegan, L. D. (2005). Not Just for Listening. Book Links, 14(5), 16-19.

Grover, S., \& Hannegan, L. D. (2012). Listening to learn: Audiobooks supporting literacy. Chicago: American Library Association. Retrieved from ProQuest Ebook Central.

Harmer, J. (1998). How to teach English. Essex: Pearson Educated Limited.

Holum, A., \& Gahala, J. (2001). Critical issue: Using technology to enhance literacy instruction (A document resume). Retrieved from https://eric.ed.gov/?id=ED4 80229.

Irwin, W. (2009). Reading audio books. Philosophy and Literature, 33, 358-368.

Kendeou, P., Van Den Broek, P., Helder, A., \& Karlsson, J. (2014). A cognitive view of reading comprehension: Implications for reading difficulties. Learning Disabilities Research \& Practice, 29(1), 10-16.

Krashen, S. (2004). The case for narrow reading. Language Magazine, 3(5), 17-19.

Larson, L. C. (2015). E-Books and audiobooks. The Reading Teacher, 69(2), 169-177.

MacArthur, C. A., Ferretti, R. P., Okolo, C. M., \& Cavalier, A. R. (2001). Technology applications for students with literacy problems: A critical review. The Elementary School Journal, 101(3), 273-301.

Maboe, E., Smith, C.G.A., Banoobhai, M. \& Makgatho, M. (2018). Implementing tablets to teach Reading in Grade 5. Reading \& Writing, 9(1), 1-10.

Paquette, K. R., \& Rieg, S. A. (2008). Using music to support the literacy development of young English language learners. Early Childhood Education Journal, 36(3), 227-232.

Robinson, B. (2018). Look Read Listen. Publishers Weekly, 265(29), 68.

Shokoff, J. (2001). What is an audiobook?. The Journal of Popular Culture, 34(4), 171-181.

Stone, R. (2008). Best practices for teaching reading: what award-winning classroom teachers. London: Corwin Press.

Wolfson, G. (2008). Using audiobooks to meet the needs of adolescent readers. American Secondary Education, 36(2), 105-114.

Whittingham, J., Huffman, S., Christensen, R., \& McAllister, T. (2013). Use of audiobooks in a school library and positive effects of struggling readers' participation in a library-sponsored audiobook club. School Library Research, 16. 
Muhammad Riswanda Imawan \& Ashadi

Yingling, J. (1998). A Study of audiobook users at the Salem, Ohio Public Library (A Thesis). Retrieved from https://eric.ed.gov/?id=ED424859 